\title{
Diagnostic Significance of Antibody to Intrinsic Factor
}

\author{
A. G. WANGEL,* M.D., M.R.A.C.P.; K. F. R. SCHILLER, † M.A., B.M., B.CH., M.R.C.P.
}

Brit. med. F., 1966, 1, 1274-1276

A circulating substance present in patients with pernicious anaemia and inhibiting the action of intrinsic factor was first demonstrated independently by Schwartz (1958) and Taylor (1959). Subsequent work has confirmed that this substance has the characteristics of an antibody (Abels et al., 1963a; Ardeman and Chanarin, 1963). Its action is thought to be specifically directed against human intrinsic factor (Ramsay and Herbert, 1965), and it is thus an autoantibody, though cross-reactions with hog intrinsic factor do occur with certain techniques (Schwartz, 1958; Taylor and Morton, 1959; Lowenstein et al., 1961 ; Gullberg and Kistner, 1963). Using a charcoal absorption technique, Ardeman and Chanarin (1963) detected antibody to intrinsic factor in $57 \%$ of patients with pernicious anaemia. Other methods, such as starch-gel electrophoresis (Jeffries et al., 1962), dialysis (Abels et al., 1963b; Ramsey and Herbert 1965), and tests in vivo (Schwartz, 1958 ; Taylor, 1959), yield a lower proportion of positive results.

Antibody to intrinsic factor has not been found in healthy control subjects (Ardeman and Chanarin, 1963 ; te Velde et al., 1964 ; Ramsey and Herbert, 1965). However, apart from its well-documented association with pernicious anaemia of the adult type, the antibody has also been found in those cases of juvenile pernicious anaemia in which histamine-fast achlorhydria and atrophic changes in the gastric mucosa are encountered (Herbert et al., 1964 ; McIntyre et al., 1965). The antibody has not been demonstrated in those patients with juvenile pernicious anaemia who have a selective lack of intrinsic factor secretion and in whom the secretion of acid and the histology of the stomach are both normal (McIntyre et al., 1965). The presence of antibody to intrinsic factor in 6 to $7 \%$ of patients with Graves's disease (Doniach and Roitt, 1964) emphasizes the close relationship between thyroid disease and pernicious anaemia.

The possible role of the antibody in the pathogenesis of pernicious anaemia is of great theoretical interest. However, the purpose of this communication is to draw attention to the usefulness of the test for the detection of antibody to intrinsic factor as a screening procedure and to the diagnostic value of a positive result.

\section{Material and Methods}

A survey was carried out to determine the prevalence of pernicious anaemia and "latent pernicious anaemia" (see below) in patients who had received ${ }^{13} 1 \mathrm{I}$ treatment for hyperthyroidism. Of 423 patients who had been treated at the Department of Radiotherapy, Churchill Hospital, Oxford, during 1951 to 1964 300 were available for study. One hundred and four control subjects were matched against the patients in a ratio of $1: 3$ on the basis of age and sex. The screening tests employed are shown in Table I, together with the criteria by which selection for further investigation was made. The detailed results of the survey will appear in subsequent papers (Schiller, Spray, Wright, and Wangel, in preparation). In this paper only those patients who had antibody to intrinsic factor are discussed.

\footnotetext{
- Nuffield Dominions Clinical Assistant, Nuffield Department of Clinical Medicine and the Radcliffe Infirmary, Oxford.

t Senior Registrar in Medicine, Nuffield Department of Clinical Medicine and the Radcliffe Infirmary, Oxford.
}

Antibody to intrinsic factor was looked for by a modification of the method of Ardeman and Chanarin (1963), as outlined in Table II. Antibody to intrinsic factor was considered to be present when the amount of ${ }^{58} \mathrm{Co}-\mathrm{B}_{12}$ bound by normal gastric juice in the presence of test serum (B-D) was less than $80 \%$ of the amount bound by gastric juice in the presence of pooled normal serum (A-C). Serum vitamin-B $B_{12}$ levels were measured by microbiological assay, Lactobacillus leichmannii being used as the test organism. In this laboratory the great majority of patients with pernicious anaemia in relapse have serum vitamin-B $B_{12}$ levels of less than $100 \mu \mu \mathrm{g} . / \mathrm{ml}$.; an occasional patient may have a level between 100 and $170 \mu \mu \mathrm{g} . / \mathrm{ml}$. Tests of ${ }^{58} \mathrm{Co}-\mathrm{B}_{12}$ absorption were performed by the faecal excretion method (Heinle et al., 1952) or by whole-body counting (Warner and Oliver, 1966). For the purpose of the present study a calculated absorption of $50 \%$ or less was regarded as abnormal. Gastric parietal-cell antibodies were detected by the immunofluorescent technique of Coons and Kaplan (1950). The Crosby-Kugler capsule (Crosby and Kugler, 1957), as modified by Salem et al. (1965), was used to obtain gastric biopsy specimens, which were assessed by Dr. W. C. D. Richards. Two patients (Cases 22 and 23) were unwilling to undergo gastric biopsy. Because of the close correlation between the assessment of the degree of gastric atrophy by biopsy and barium-meal examination (Bock et al., 1963), the latter method alone was used in these two cases. Secretion of gastric hydrochloric acid was measured by the augmented histamine test (Kay, 1953). In accordance with Callender et al. (1960) achlorhydria was considered to be present when the acidity of the gastric juice failed to fall by more than one $\mathrm{pH}$ unit and did not reach a $\mathrm{pH}$ of 3.5 or less during the test. The tubeless azuresin test was carried out where the augmented histamine test was contraindicated.

TABLE I.-Investigations Used in Search for Pernicious Anaemia and Latent Pernicious Anaemia in 300 Thyrotoxic Patients Treated with

\begin{tabular}{l|c|l}
\hline \multicolumn{1}{c|}{ Screening Tests } & $\begin{array}{c}\text { Criteria for } \\
\text { Admission to Hospital }\end{array}$ & \multicolumn{1}{c}{ Final Tests } \\
\hline Haemoglobin and blood film & $\begin{array}{l}<11 \mathrm{~g} . / 100 \mathrm{ml} \text {. with } \\
\text { macrocytosis }\end{array}$ & $\begin{array}{l}\text { Barium meal } \\
\text { Gastric biopsy } \\
\text { Gastric acidity } \\
\text { Vit. B12 absorption } \\
\text { Sternal marrow biopsy }\end{array}$ \\
$\begin{array}{l}\text { Serum vit. B12 level } \\
\begin{array}{l}\text { Gastric parietal cell antibodies } \\
\text { Intrinsic factor antibodies } \\
\text { Thyroid antibodies } \\
\text { Protein-bound iodine }\end{array}\end{array}$ & $\begin{array}{l}\text { Positive } \\
\text { Positive }\end{array}$ & \\
\hline
\end{tabular}

TABLE II.-Test for Presence of Antibody to Intrinsic Factor

\begin{tabular}{|c|c|c|c|c|c|}
\hline & $\begin{array}{c}\text { A } \\
\text { Control } \\
\text { Serum }\end{array}$ & $\begin{array}{c}\text { B } \\
\text { Test } \\
\text { Serum }\end{array}$ & $\begin{array}{l}\text { C } \\
\text { Control } \\
\text { Serum } \\
\text { Blank }\end{array}$ & $\begin{array}{c}\text { D } \\
\text { Test } \\
\text { Serum } \\
\text { Blank }\end{array}$ & $\begin{array}{l}{ }^{88} \mathrm{Co}-\mathrm{B}_{12} \\
\text { Standard }\end{array}$ \\
\hline $\begin{array}{l}\text { Normal pooled gastric juice } \\
\text { 1:10 dilution (ml.) } \\
\text { Test serum (ml.) } \\
\text { Normal pooled serum (mi.) } \\
\text { Normal saline (ml.).. }\end{array}$ & $\frac{4 \cdot 0}{1.0}$ & $\begin{array}{l}4.0 \\
0.5 \\
0.5 \\
-\end{array}$ & $\begin{array}{l}\bar{Z} \\
\overline{0.5} \\
4.5\end{array}$ & $\frac{\overline{0.5}}{4.5}$ & $\bar{z}$ \\
\hline${ }^{\triangle 8} \mathrm{Co}-\mathrm{B}_{12}, 40 \mathrm{~m} \mu \mathrm{g} . / \mathrm{ml}$. (ml.) & $\begin{array}{l}\text { Mix, s } \\
\text { tem } \\
1 \cdot 0 \\
\text { Mix, } 8 \\
\text { tem }\end{array}$ & $\begin{array}{r}\text { tand } 20 \\
\text { perature } \\
1 \cdot 0 \\
\text { tand } 20 \\
\text { perature }\end{array}$ & $\begin{array}{l}\text { minutes at } \\
\int_{\text {minutes at }}^{1.0}\end{array}$ & room $1 \cdot 0$ & 1.0 \\
\hline $\begin{array}{ccc}\text { Activated charcoal (approx.) } \\
\text { (mg.) } & \cdots & \cdots\end{array}$ & $\begin{array}{l}20 \\
\text { Mix, } \\
\text { fuge } \\
\text { in } 4\end{array}$ & $\begin{array}{l}20 \\
\text { tand } 10 \\
\text { and co } \\
\mathrm{ml} \text {. of } \mathrm{cl}\end{array}$ & $\begin{array}{l}\text { 20 } \\
\text { minutes, } \\
\text { ount radioa } \\
\text { lear supern }\end{array}$ & $\begin{array}{l}1 \quad 20 \\
\text { centri- } \\
\text { activity } \\
\text { natant }\end{array}$ & $\begin{array}{c}\text { Count 4-ml. } \\
\text { aliquot }\end{array}$ \\
\hline
\end{tabular}




\section{Results}

Sera from 299 patients were tested for the presence of antibody to intrinsic factor. Fourteen patients had the antibody, and all but one of these also had gastric parietal-cell antibodies. None of the sera from the control subjects contained antibody to intrinsic factor. Table III presents the results of the investigations carried out in the 14 patients who possessed the antibody.

Pernicious Anaemia.-There were four patients in this group. All but one were already known to have this condition and were receiving treatment when the survey was begun.

Latent Pernicious Anaemia.-Callender and Spray (1962) defined latent pernicious anaemia as a state in which "the secretion of intrinsic factor is reduced and the stage is set for the development of the full picture of vitamin- $B_{12}$ deficiency at any time, although the subject appears in excellent health and has no signs of anaemia or central nervous disorder." For the purpose of the present survey this definition was amplified so that latent pernicious anaemia was considered to be present when the subject was well but had gastritis and/or gastric atrophy, achlorhydria, and impaired vitamin- $\mathrm{B}_{12}$ absorption correctable by intrinsic factor. Note was also taken of macrocytosis, macronormoblastic or megaloblastic erythropoiesis, gastric parietal-cell and intrinsic factor antibodies, and low serum vitamin- $\mathrm{B}_{12}$ levels. A diagnosis of "latent pernicious anaemia" does not imply that in every patient with this condition clinical pernicious anaemia will eventually develop. Four patients fulfilled the three major criteria of latent pernicious anaemia (Cases 94, 110, 114, and 193). None was anaemic, and though macrocytosis was evident in two aspiration of sternal marrow revealed normoblastic erythropoiesis in the three patients, who underwent this investigation. The serum level of vitamin $\mathrm{B}_{12}$ was definitely low in only one patient (Case 94).

Probable Latent Pernicious Anaemia.-Patients were grouped under this heading when all investigations that could be carried out yielded results characteristic of latent pernicious anaemia, but when the data on the three major criteria remained incomplete, either because the patient declined full investigation (Cases 85 and 231) or because there were obvious technical errors in the tests (Case 99). Three patients were considered to have probable latent pernicious anaemia. One (Case 85) had a macrocytic anaemia with macronormoblastic erythropoiesis and impaired absorption of ${ }^{58} \mathrm{Co}-\mathrm{B}_{12}$. The serum folate level and the excretion of faecal fat were normal, but the patient refused further investigation. The second patient (Case 99) had histamine-fast achlorhydria and histological evidence of gastric atrophy. However, the vitamin- $\mathrm{B}_{12}$ absorption test depends on faecal collections, which in this case were incom- plete. The calculated absorption was therefore in all likelihood erroneously high. Moreover, direct assay in vitro of the intrinsic factor content of the gastric juice was carried out by a method already described (Wangel and Callender, 1965). This patient secreted less than 10 units of intrinsic factor per hour both before and after histamine stimulation, the range for patients with proved pernicious anaemia being $0-400$ units per hour (Wangel, unpublished results). The third patient (Case 231) had histological evidence of gastric atrophy, together with a subnormal serum level of vitamin $B_{12}$ and achlorhydria to the azuresin test, but declined tests of vitamin- $B_{12}$ absorption.

Possible Precursory Stage of Pernicious Anaemia.-Results which were not characteristic of pernicious anaemia or latent pernicious anaemia as defined above were found in one patient with circulating antibody to intrinsic factor (Case 164). She was a woman of 69 in whom the haemoglobin, blood film, marrow smear, and serum vitamin- $\mathrm{B}_{12}$ level were all normal. During the augmented histamine test the $p \mathrm{H}$ of the gastric juice fell by three $p \mathrm{H}$ units from 7 to 4 . Nevertheless, only $15 \mathrm{ml}$. of gastric juice and $0.30 \mathrm{mEq}$ of $\mathrm{HCl}$ were secreted in the hour following histamine stimulation. The gastric biopsy specimen showed mild but definite atrophic gastritis. The patient absorbed $56 \%$ of a $0.5 \mu \mathrm{g}$. dose of ${ }^{58} \mathrm{Co}$-vitamin $\mathrm{B}_{12}$ given orally. Assay of the gastric juice in vitro showed that the basal secretion of intrinsic factor was 400 units per hour, rising to 900 units per hour after stimulation with histamine. Normal subjects usually secrete between 6,000 and 16,000 units of intrinsic factor in one hour after histamine stimulation (Wangel and Callender, 1965).

No further investigation was possible in two patients (Cases 106 and 238). The former was 87 years of age and blind, the latter declined further tests.

Table IV shows the frequency with which pernicious anaemia and latent or probable latent pernicious anaemia was found in patients with and without antibody (Table IV). It can be seen that of the 12 patients with the antibody who underwent further investigation 11 were finally placed in one of these three categories. By contrast only 7 of 44 patients without

TABLE IV.-Incidence of Pernicious Anaemia and Related States in 78 Patients with Positive Screening Tests

\begin{tabular}{|c|c|c|c|c|}
\hline & & & \multicolumn{2}{|c|}{ Intrinsic Factor Antibodies } \\
\hline & & & Present & Absent \\
\hline $\begin{array}{l}\text { Pernicious anaemia } \\
\text { Latent pernicious anaemia } \\
\text { Probable latent pernicious } \\
\text { Possible precursory stage } \\
\text { No evidence of foregoing } \\
\text { Not investigated further.. }\end{array}$ & $\begin{array}{c}\text { rnic } \\
\cdots \\
\cdots\end{array}$ & $\begin{array}{cc}\ldots & \ldots \\
\cdots & \cdots \\
\text { s anaemia } \\
\cdots & \cdots \\
\cdots & \cdots\end{array}$ & $\left.\begin{array}{r}4 \\
4 \\
3\end{array}\right\} \begin{array}{r}11 \\
1 \\
0 \\
2\end{array}$ & $\left.\begin{array}{l}2 \\
5 \\
0\end{array}\right\} \begin{array}{r}7 \\
0 \\
37 \\
20 \\
\end{array}$ \\
\hline & 14 & 64 \\
\hline
\end{tabular}

TABLE III.-Results of Investigations in and Final Classification of 14 Patients with Antibody to Intrinsic Factor

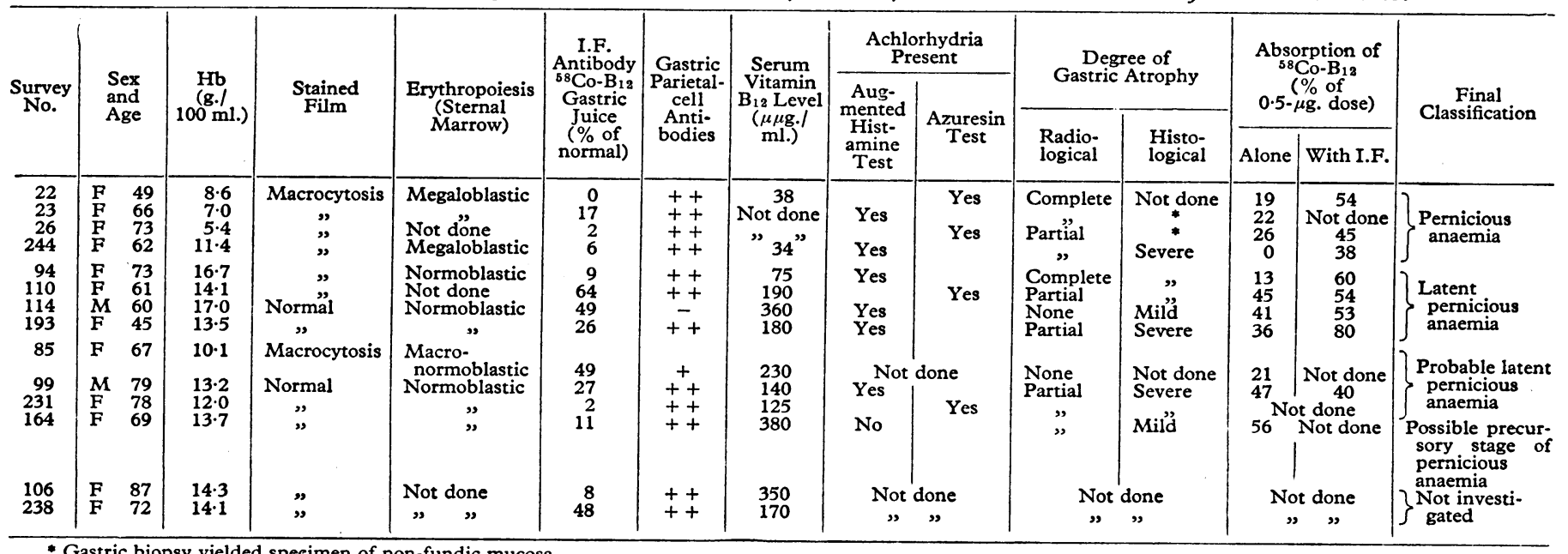


antibody to intrinsic factor who underwent further tests were similarly classified.

\section{Discussion}

In the present survey the prevalence of intrinsic factor antibody was $4.7 \%$. This is slightly less than the 6 to $7 \%$ reported by Doniach and Roitt (1964) in patients with Graves's disease. However, it is difficult to compare the two figures without knowing the number and age and sex distribution of Doniach and Roitt's patients. The finding of intrinsic factor antibody in healthy relatives of patients with pernicious anaemia or thyroid disease has been described (te Velde et al., 1964 ; Sharpstone and James, 1965), but attention has not previously been drawn to the implication of this finding. The data presented above indicate that while a negative test for intrinsic factor antibody is of no value a positive result strongly suggests that either pernicious anaemia or an intermediate stage in the development of this condition is present. The simplicity and apparent specificity of the test make it a valuable screening procedure.

It is of some interest that one patient with antibody to intrinsic factor secreted a small amount of acid after maximal histamine stimulation. We have found no similar case in the literature. However, in the course of a family study of pernicious anaemia McIntyre et al. (1959) found that the secretion of intrinsic factor may in some patients fail before acid secretion. In this particular patient the gastric lesion was not as severe as is the rule in overt pernicious anaemia, and the absorption of labelled vitamin $B_{12}$ was near the lower limit of normal. Unfortunately the vitamin- $B_{12}$ absorption test was carried out by the faecal excretion method before the introduction of wholebody counting techniques in this hospital. It is known that by the faecal method any error due to incomplete collection is in the direction of falsely high values for absorption. It is possible, therefore, that the patient's ability to absorb vitamin $\mathrm{B}_{12}$ was overestimated. The result of intrinsic-factor assay in vitro supported the conclusion that the secretion of intrinsic factor was grossly subnormal, though not yet reduced to the degree evident in patients with pernicious anaemia. Follow-up study of this patient will reveal whether the impairment of gastric function is progressive. It will also be necessary to watch closely those patients who were considered to have latent or probable latent pernicious anaemia. It is still uncertain what proportion of these patients will eventually progress to clinical pernicious anaemia (Callender and Spray, 1962).

\section{Summary}

Three hundred patients treated for hyperthyroidism with ${ }^{131} \mathbf{I}$ were studied, with particular reference to the prevalence of overt and latent pernicious anaemia. In the course of the study 14 patients were found to have antibody to intrinsic factor. Twelve of these underwent further investigation, and all but one were found to have either overt, latent, or probable latent pernicious anaemia.

It is suggested that testing for the presence of antibody to intrinsic factor is of value in screening patients for the presence of pernicious anaemia and latent pernicious anaemia. A positive result is highly suggestive of the presence of either of these conditions, though no significance can be attached to a negative test.

ADDENDUM.-Since this paper was submitted for publication antibody to intrinsic factor has been described in occasional cases of iron-deficiency anaemia (Irvine, 1965). Furthermore, Ardeman and co-workers (1966) have reported a small number of patients with thyroid disease in whom the secretion of intrinsic factor was normal or only moderately reduced in the presence of circulating antibody to intrinsic factor. In most instances, however, the presence of the antibody can be taken to imply gross impairment of intrinsic factor secretion (Herbert, 1965 ; Irvine, 1966).

We would like to thank the physicians of the United Oxford Hospitals and the Oxford Region for allowing us to investigate patients under their care, and Dr. Frank Ellis, consultant radiotherapist, for his co-operation throughout the survey. Dr. F. H. Kemp kindly reported on the barium-meal films. We are indebted to Dr. G. H. Spray for estimations of serum vitamin-B $B_{12}$ levels, Dr. R. Wright for serological tests for gastric parietal cell antibiodies, and Mr. G. T. Warner for tests of vitamin-B $B_{12}$ absorption. We are especially grateful to Professor L. J. Witts for his encouragement and interest and for allowing us the facilities of the Nuffield Department of Clinical Medicine. The work was supported in part by a grant from the Medical Research Council.

\section{REFERENCES}

Abels, J., Bouma, W., Jansz, A., Woldring, M. G., Bakker, A., and Nieweg, H. O. (1963a). Э. Lab. clin. Med., 61, 893.

and Nieweg, H. O. (1963b). Biochim. biophys. Acta (Amst.), 71, 227. ,

Ardeman, S., and Chanarin, I. (1963). Lancet, 2, 1350.

Ardemarin, I., Krafchik, B., and Singer, W. (1966). Quart. F. Med., N.S. 35. In press. Bock, O. A. A., Kemp, F. H., and Richards, W. C. D. (1963). Brit. F.
Radiol., 36, 578

Coons, A. H., and Kaplan, M. H. (1950). 7. exp. Med., 91, 1.

Callender, S. T., Retief, F. P., and Witts, L. J. (1960). Gut, 1, 326.

and Spray, G. H. (1962). Brit. F. Haemat., 8, 230.

Crosby, W. H., and Kugler, H. W. (1957). Amer. F. dig. Dis., 2, 236.

Doniach, D., and Roitt, I. M. (1964). Semin. Hemat., 1, 313.

Gullberg, R., and Kistner, S. (1963). Acta med. scand., 174, 573.

Heinle, R. W., Welch, A. D., Scharf, V., Meacham, G. C., and Prusoff, W. H. (1952). Trans. Ass. Amer. Phycns, 65, 214.

Herbert, V. (1965). Gastroenterology, 49, 218.

Streiff, R. R., and Sullivan, L. W. (1964). Medicine (Baltimore), 43, 679 .

Irvine, W. J. (1965). New Engl. 7. Med., 273, 432.

- (1966). Clin. exp. Immunol., 1, 99.

Jeffries, G. H., Hoskins, D. W., and Sleisenger, M. H. (1962). F. clin. Invest., 41, 1106.

Kay, A. W. (1953). Brit. med. 7., 2, 77.

Lowenstein, L., Cooper, B. A., Brunton, L., Gartha, S., and Kerner, K. (1961). f.' clin. Invest., 40, 1656.

McIntyre, O. R., Sullivan, L. W., Jeffries, G. H., and Silver, R. H. (1965). New Engl. F. Med., 272, 981.

McIntyre, P. A., Hahn, R., Conley, C. L., and Glass, B. (1959). Bull. fohns Hopk. Hosp., 104, 309.

Ramsey, C., and Herbert, V. (1965). 7. Lab. clin. Med., 65, 143.

Salem, S. N., Salt, R. H., and Truelove, S. C. (1965). Gut, 6, 99.

Schwartz, M. (1958). Lancet, 2, 61.

Sharpstone, P., and James, D. G. (1965). Ibid., 1, 246.

Tayilor, K. B. (1959). Ibid., 2, 106.

and Morton, J. A. (1959). F. Path. Bact., 77, 117.

te Velde, K., Abels, J., Anders, G. J. P. A., Arends, A., Hoedemacker, Ph. J., and Nieweg, H. O. (1964). Ұ. Lab. clin. Med., 64, 177.

Wangel, A. G., and Callender, S. T. (1965). Brit. med. F., 1, 1409.

Warner, G. T., and Oliver, R. (1966). Phys. in Med. Biol., 11, 83. 